\title{
Seasonal Incidence of Major Pests of Brinjal
}

\author{
T.S. Kadgonkar*, A.S. Bagde, V.J. Deshmukh and A.S. Mali \\ Biranje Panand, E word, Kasaba Bawada, Kolhapur, Maharashtra-416006, India \\ *Corresponding author
}

\begin{tabular}{l} 
K e y w o r d s \\
$\begin{array}{l}\text { Brinjal, Leaf hopper, } \\
\text { Aphid, White fly, } \\
\text { Leucinodes orbonalis } \\
\text { Guenee, Seasonal } \\
\text { incidence }\end{array}$ \\
\hline Article Info \\
$\begin{array}{l}\text { Accepted: } \\
18 \text { August } 2018 \\
\text { Available Online: } \\
10 \text { September } 2018\end{array}$ \\
\hline
\end{tabular}

A B S T R A C T

The experiment was conducted during Rabi 2016 at horticultural farm, college of agriculture, Kolhapur. The incidence of leaf hopper (Amrasca biguttula biguttula) was maximum during January, $1^{\text {st }}$ Standard Week $(\mathrm{SW})$ and minimum during February $\left(8^{\text {th }}\right.$ $\mathrm{SW}$ ). The incidence of white fly (Bemicia tabaci) was maximum during January, $1^{\text {st }}$ Standard Week (SW) and minimum during February $\left(8^{\text {th }} \mathrm{SW}\right)$. Both these insects showed significant negative correlation with both maximum and minimum temperature while a positive correlation was revealed with mean relative humidity. The incidence of aphid (Aphis gossypi) was minimum during November $\left(45^{\text {th }} \mathrm{SW}\right)$ and maximum during February $\left(8^{\text {th }} \mathrm{SW}\right)$. Both these insects showed significant positive correlation with both maximum and minimum temperature while a negative correlation was revealed with mean relative humidity. The incidence of shoot and fruit borer, Leucinodes orbonalis Guenee was observed during Nov. - Dec. with peak infestation during January $\left(4^{\text {th }} \mathrm{SW}\right)$. The percent shoot damage was positively correlated with both maximum and minimum temperature while negatively correlated with mean relative humidity. While percent fruit infestation revealed a non-significant positive correlation with maximum and minimum temperature while negative correlation with mean relative humidity.

\section{Introduction}

Brinjal or Eggplant, Solanum melongena (Linn.), family Solanaceae is native of India. Brinjal is worldwide known as aubergine or guinea squash which is most popular and principle vegetable crop hence regarded as "King of vegetable". It is important due to its nutritional, medicinal as well as commercial value. $100 \mathrm{~g}$ edible portion of brinjal supply $40 \mathrm{~g}$ carbohydrate, $1.40 \mathrm{~g}$ proteins, $0.30 \mathrm{~g}$ mineral and vitamins viz., $\mathrm{A}, \mathrm{B}$ and $\mathrm{C}$ (Aycord, 1983). It is one of the most common and popular crop grown in India and also other parts of the world.
In the brinjal field, various pests prevail during seedling to harvesting stage and the loss caused by brinjal pests vary from season to season depending upon environmental factors (Gangwar and Sachin, 1981)

The crop is attacked by number of insect pests but the major ones include jassid (Amrasca biguttula biguttula), aphid (Aphis gossypii), white fly (Bemisia tabaci) and shoot and fruit borer (Leucinodes orbonalis Guenee). Pest abundance and distribution changes with abiotic factors and therefore meteorological parameters play a pivotal role in the biology of any pest. 


\section{Materials and Methods}

Field experiment was conducted at horticultural farm, college of agriculture, Kolhapur, India situated at $569 \mathrm{~m}$ above mean sea level on $16.41^{0}$ North to $74.13^{0}$ East latitude on brinjal variety, Shirgaon Kata in Randomized Block Design (RBD) during Rabi season 2016 with three replications. The plot size was $2.70 \times 1.80 \mathrm{~m}^{2}$ with $75 \times 75 \mathrm{~cm}^{2}$ spacing. The incidence of selected pests was recorded from sowing to harvesting of the crop.

Observations on the population of sucking pests were recorded on three leaves one each from top, middle and bottom canopy of the five plants selected randomly in each replication. The data on the infestation of fruits were recorded at the time of picking. Fruits from each plot will be harvested separately and examined carefully for the infestation of $L$. orbonalis the fruits showing holes with plugged excreta will be considered as damaged ones. Weekly data on different abiotic parameters were also recorded. Data so obtained were then subjected to statistical analysis for correlation and test of significance.

\section{Results and Discussion}

The data (Table 1, 2 and 3) revealed the abundance of different insect pests in brinjal agroecosystem. The incidence of aphid (Aphis gossypii) varied from 2.4-9.6 per five plants and was maximum during $8^{\text {th }}$ Standard week (SW) and minimum during November $\left(45^{\text {th }} \mathrm{SW}\right)$. The incidence of leaf hopper (Amrasca biguttula biguttula) varied from 2.8 -8.0 per five plants and was maximum during $1{ }^{\text {st }}$ Standard week (SW) and goes decreasing February $\left(8^{\text {th }} \mathrm{SW}\right)$. The incidence of white fly (Bemisia tabaci) was maximum (6.5 /five plants) during January ( $\left.{ }^{\text {st }} \mathrm{SW}\right)$ and goes decreasing February $\left(8^{\text {th }}\right.$ SW $)$. Overall incidence was more during January. Aphid showed significant positive correlation with both maximum and minimum temperature while negative correlation with mean relative humidity.

Both these insects i.e. leaf hopper and white fly showed significant negative correlation with both maximum and minimum temperature while a positive correlation was observed with mean relative humidity. Significant negative correlation of leafhopper and white fly with temperature in brinjal agroecosystem was also reported earlier (Chandrakumar et al., 2008).

The incidence of Brinjal Shoot and Fruit Borer (BSFB), Leucinodes orbonalis Guenee commenced during Nov. - Dec. with peak shoot infestation during Jan. $\left(4^{\text {th }} \mathrm{SW}\right)$. The incidence of fruit borer was noticed during Dec. with peak infestation during Feb. $6^{\mathrm{th}}$ SW). The percent shoot damage was positively correlated with both maximum and minimum temperatures while negatively correlated with mean relative humidity. The effect of abiotic factors viz., maximum temperature, minimum temperature and mean relative humidity was significantly correlated with population fluctuation $(\mathrm{r}=0.2311$, 0.0502 and -0.2526 respectively). While percent fruit infestation revealed a nonsignificant positive correlation with maximum and minimum temperature and negative significant correlation with mean relative humidity.

Earlier reports also suggest that maximum and minimum temperature and abundance of brinjal shoot and fruit borer showed a positive correlation (Shukla and Khatri, 2010 and Mathur et al., 2012). Many of the earlier workers have also reported the incidence of shoot and fruit borer throughout the year in different regions of South East Asia (Khan and Al-salem, 2007 and Mall et al., 1992). 
Table.1 Population dynamics of sucking pest of brinjal under field condition

\begin{tabular}{|c|c|c|c|c|c|c|c|c|c|}
\hline \multirow{2}{*}{$\begin{array}{l}\text { Week after } \\
\text { transplanting } \\
\text { (WAT) }\end{array}$} & \multirow{2}{*}{$\begin{array}{c}\text { Meteorological } \\
\text { week } \\
\text { (MW) }\end{array}$} & \multirow{2}{*}{$\begin{array}{l}\text { No. of } \\
\text { Aphids/ } \\
\text { leaf }\end{array}$} & \multirow{2}{*}{$\begin{array}{c}\text { No. of } \\
\text { Jassids/ } \\
\text { Leaf }\end{array}$} & \multirow{2}{*}{$\begin{array}{c}\text { No. of } \\
\text { Whiteflies/ } \\
\text { leaf }\end{array}$} & \multicolumn{2}{|c|}{ Temperature $\left({ }^{0} \mathrm{C}\right)$} & \multicolumn{2}{|c|}{ Humidity (\%) } & \multirow{2}{*}{$\begin{array}{c}\text { Average } \\
\text { relative } \\
\text { humidity }(\%)\end{array}$} \\
\hline & & & & & Maximum & Minimum & Morning & Evening & \\
\hline 1 & 45 & 2.4 & 2.8 & 2.3 & 31.20 & 10.60 & 68 & 48 & 58 \\
\hline 2 & 46 & 2.9 & 3.6 & 3.9 & 30.80 & 12.30 & 73 & 57 & 65 \\
\hline 3 & 47 & 3.1 & 4.2 & 4.3 & 30.40 & 9.50 & 76 & 51 & 64 \\
\hline 4 & 48 & 3.7 & 5.6 & 4.9 & 31.40 & 8.70 & 86 & 54 & 70 \\
\hline 5 & 49 & 4.0 & 6.2 & 3.4 & 30.50 & 11.80 & 85 & 51 & 68 \\
\hline 6 & 50 & 4.6 & 6.6 & 5.7 & 30.60 & 16.90 & 81 & 52 & 67 \\
\hline 7 & 51 & 4.9 & 7.4 & 6.0 & 30.70 & 10.20 & 84 & 54 & 69 \\
\hline 8 & 52 & 5.6 & 7.7 & 6.3 & 31.81 & 8.20 & 80 & 50 & 65 \\
\hline 9 & 01 & 6.8 & 8.0 & 6.5 & 31.48 & 9.94 & 80 & 50 & 65 \\
\hline 10 & 02 & 6.4 & 7.4 & 5.6 & 29.61 & 8.10 & 80 & 35 & 58 \\
\hline 11 & 03 & 6.2 & 6.9 & 5.4 & 29.78 & 11.31 & 79 & 14 & 47 \\
\hline 12 & 04 & 7.2 & 6.7 & 5.6 & 31.65 & 11.90 & 85 & 37 & 61 \\
\hline 13 & 05 & 7.8 & 5.6 & 4.8 & 32.32 & 12.70 & 87 & 28 & 57 \\
\hline 14 & 06 & 8.3 & 5.2 & 4.6 & 33.50 & 12.98 & 84 & 32 & 58 \\
\hline 15 & 07 & 9.0 & 5.4 & 4.9 & 32.38 & 12.77 & 85 & 31 & 58 \\
\hline 16 & 08 & 9.6 & 5.1 & 4.4 & 35.54 & 13.45 & 86 & 22 & 54 \\
\hline
\end{tabular}


Table.2 Population dynamics of shoot and fruit borer of brinjal under field condition

\begin{tabular}{|c|c|c|c|c|c|c|c|c|}
\hline \multirow{2}{*}{$\begin{array}{c}\text { Week after } \\
\text { transplanting } \\
\text { WAT }\end{array}$} & \multirow{2}{*}{$\begin{array}{c}\text { Meteorological } \\
\text { week } \\
\text { (MW) }\end{array}$} & \multirow{2}{*}{$\begin{array}{c}\text { Shoot } \\
\text { infestation } \\
(\%)\end{array}$} & \multirow{2}{*}{$\begin{array}{c}\text { Fruit } \\
\text { infestation } \\
(\%)\end{array}$} & \multicolumn{2}{|c|}{ Temperature $\left({ }^{0} \mathrm{C}\right)$} & \multicolumn{2}{|c|}{ Relative Humidity (\%) } & \multirow{2}{*}{$\begin{array}{c}\text { Average } \\
\text { relative } \\
\text { humidity } \\
(\%)\end{array}$} \\
\hline & & & & Maximum & Minimum & Morning & Evening & \\
\hline 1 & 45 & 0 & 00 & 31.20 & 10.60 & 68 & 48 & 58 \\
\hline 2 & 46 & 0 & 00 & 30.80 & 12.30 & 73 & 57 & 65 \\
\hline 3 & 47 & 1.02 & 00 & 30.40 & 9.50 & 76 & 51 & 64 \\
\hline 4 & 48 & 2.3 & 00 & 31.40 & 8.70 & 86 & 54 & 70 \\
\hline 5 & 49 & 2.8 & 3.13 & 30.50 & 11.80 & 85 & 51 & 68 \\
\hline 6 & 50 & 3.25 & 5.17 & 30.60 & 16.90 & 81 & 52 & 67 \\
\hline 7 & 51 & 3.7 & 6.76 & 30.70 & 10.20 & 84 & 54 & 69 \\
\hline 8 & 52 & 4.55 & 8.23 & 31.81 & 8.20 & 80 & 50 & 65 \\
\hline 9 & 01 & 4.5 & 12.93 & 31.48 & 9.94 & 80 & 50 & 65 \\
\hline 10 & 02 & 4.1 & 14.46 & 29.61 & 8.10 & 80 & 35 & 58 \\
\hline 11 & 03 & 4.3 & 15.97 & 29.78 & 11.31 & 79 & 14 & 47 \\
\hline 12 & 04 & 4.8 & 18.23 & 31.65 & 11.90 & 85 & 37 & 61 \\
\hline 13 & 05 & 4.6 & 24.15 & 32.32 & 12.70 & 87 & 28 & 57 \\
\hline 14 & 06 & 4.45 & 30.83 & 33.50 & 12.98 & 84 & 32 & 58 \\
\hline 15 & 07 & 3.95 & 25.5 & 32.38 & 12.77 & 85 & 31 & 58 \\
\hline 16 & 08 & 3.5 & 19.5 & 35.54 & 13.45 & 86 & 22 & 54 \\
\hline
\end{tabular}


Table.3 Correlation between abiotic factors and major insect pests of brinjal during Rabi 2016, Correlation coefficient (' $r$ ') values

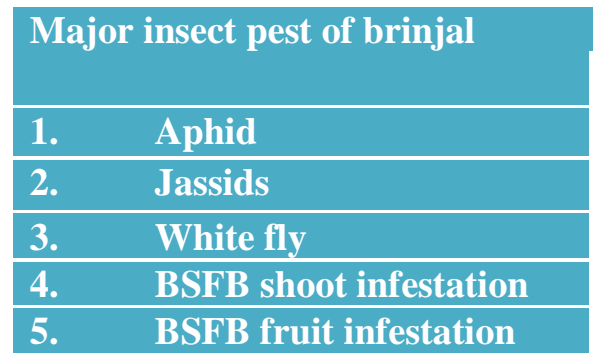

*significant at 5 per cent level

The present experiment provides a basic study for population dynamics. It can be concluded that seasonal population fluctuation of major insect pests on brinjal crop is greatly influenced by abiotic factors and peak population levels are observed during December - February. The statistically significant values indicated that occurrence of insect pests population was due to the prevailing ecological conditions. The management of brinjal pest complex during rabi sown brinjal under semiarid agroclimatic zone should therefore be promoted and tailored from November onwards using an integrated approach.

\section{References}

Aycord, W.R. 1983. The nutritional value of Indian food and planning of satisfactory diets I.C.M.R., Special Report Series No. 42.

Chandrakumar H. L., Ashok Kumar C. T., Kumar N.G., Chakravarthy A. K. and Putta Raju T.B., Seasonal occurrence of major insect pests and their natural enemies on brinjal, Curr., Biotica., 2(1), 66-69, (2008).

\section{How to cite this article:}

Kadgonkar, T.S., A.S. Bagde, V.J. Deshmukh and Mali, A.S. 2018. Seasonal Incidence of Major Pests of Brinjal. Int.J.Curr.Microbiol.App.Sci. 7(09): 2727-2731. doi: https://doi.org/10.20546/ijcmas.2018.709.338
Gangwar R. T. and Sachin J.N., Seasonal incidence and control of insect pests of brinjal with special reference to shoot and fruit borer, Leucinodes orbonalis Guen. In Meghalaya. J. Res. 2(2), 8792, (1981).

Khan A. and Al-salem S., Seasonal variation effect on airborne pollutants, J. Environ. Res. Develop., 1(3), 215-218, (2007).

Mall N. P., Pandey R.S., Singh S.V. and Singh S.K., Seasonal incidence of insect pests and estimation of the losses caused by shoot and fruit borer on brinjal, Ind. J. Entomol., 63(2), 137143, (1992).

Mathur, A., Singh, N.P. and Meena, M. 2012. Influence of seasonal variation of temperature and relative humidity levels on the developmental stages and growth index of L. orbonalis Guen. In semi-arid region of Rajasthan. Journal of Entomology Res. 35(4): 303306.

Shukla A. and Khatri S.N., Incidence and abundance of brinjal shoot and fruit borer Leucinodes orbonalis Guenee. The Bioscan. 5(2), 305-308, (2010). 